\title{
THE CLINICAL USES OF HUMAN SERUMS PRESERVED BY THE LYOPHILE PROCESS
}

\author{
By AIMS C. McGUINNESS, JOSEPH STOKES, JR., AND STUART MUDD \\ (From the Departments of Pediatrics and Bacteriology, School of Medicine, University of Penn- \\ sylvania, and from the Abington Memorial Hospital and the Children's Hospital \\ of Philadelphia, Philadelphia)
}

(Received for publication October 7, 1936)

The development of improved technical procedures for preservation, pooling and concentration have considerably facilitated the utilization of human serums in the prevention and treatment of infectious diseases. Full accounts of these procedures have already been published $(1,2)$, and preliminary reports of their clinical applications have been presented before the Society for Pediatric Research (3) and the American Pediatric Society (4). In brief, the serums used are pooled and preserved by drying in vacuo from the frozen state; the dry porous material resulting is called "lyophile" serum. It may be redissolved in as little as one-quarter its original volume of liquid.

The studies here presented consider the problem of human serum therapy with special reference to the use of serum preserved by this process in the prophylaxis and treatment of certain of the more common infectious diseases. The following list summarizes the diseases studied and the serums used:

1. Scarlet fever .......a. Convalescent serum in prophylaxis and

b. Pooled adult serum in prophylaxis.

2. Measles

b. Pooled adult serum in prophylaxis.

3. Mumps ........... Convalescent serum in prophylaxis and

b. Pooled adult serum in prophylaxis.

4. Chickenpox .......... Convalescent serum in prophylaxis.

b. Pooled adult serum in prophylaxis.

5. Erysipelas $\ldots \ldots \ldots \ldots$ Convalescent serum in treatment.

6. Whooping cough ....... Serum from vaccinated individuals in

b. Pooled adult serum in treatment.

7. German measles .... Pooled adult serum in prophylaxis.

8. Acute hemolytic strep-

tococcal infections.

Convalescent scarlet fever serum in treatment.

It has not been possible to obtain suitable control groups for the clinical evaluation of the serum. Since on hospital wards it is desirable to prevent any secondary cases of the disease in question, it is impracticable to utilize alternate cases as controls. Many of the cases came from private practice and here, likewise, it is impossible to select alternate cases for injection. From general clinical experience certain assumptions must be made concerning the probability of occurrence of an infectious disease in a particular individual according to the type of disease, the intimacy of exposure, and other well-recognized factors.

It is well recognized that such factors as individual susceptibility and exact duration and degree of exposure, as a rule, cannot be accurately determined with respect to measles, mumps and chickenpox. It is possible to determine with considerable accuracy the susceptibility of an individual to scarlet fever by means of the Dick test. In hospital practice, the presence of a positive Dick test has generally been determined prior to the administration of serum for scarlet fever prophylaxis, but in private practice families in many instances are unwilling to wait the twentyfour hours required for the Dick test before the serum is given.

In passive immunization against measles and at times also against chickenpox, the practitioner desires modification of the disease rather than complete protection. It is not clear in certain cases included in the present studies whether attenuation or complete protection was desired, but in most instances the physician's desire could be determined. Attenuation of the disease was usually preferred.

It has frequently been emphasized that the duration and degree of exposure on a hospital ward, even without special infectious precautions, are far less than in the home where the children usually play together "ad lib." For this reason the cases have been divided into hospital and home groups, since the proportion of expected secondary cases in the home exceeds that to be expected in the hospital.

Data on private cases are secured through the use of protocol outlines which are given to the attending physician when he applies for serum. ${ }^{1}$

${ }^{1} \mathrm{We}$ are indebted to Dr. John McK. Mitchell and Dr. Theodore S. Wilder for a large number of the case reports coming from outside of hospitals. 
The dosages recommended by various workers in prophylaxis against the contagious diseases for which these serums are given, vary considerably. At first, in the present studies, the dosage for all the infectious diseases was based upon cubic centimeters of serum per year of age. The standard used was $2 \mathrm{cc}$. per year of age of convalescent serum and $4 \mathrm{cc}$. per year of age of pooled adult serum. Later, it was found that some of the younger children were not receiving sufficient serum whereas older children were given more serum than was necessary. While the standard of dosage now used is probably far from being exact, according to age or weight, it is simple, requires only two sizes of serum containers (10 and $15 \mathrm{cc}$.), and thus far has given satisfactory results. The present standard of dosage follows:

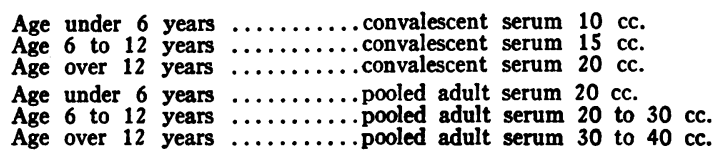

From the results outlined below these doses are considered protective.

In practically all instances, serum is given in doubly concentrated form; i.e., a dose of $30 \mathrm{cc}$. of serum is given intramuscularly in a total volume of $15 \mathrm{cc}$. If desired, this may be even further concentrated to 8 or $10 \mathrm{cc}$. by reducing correspondingly the volume of distilled water used to dissolve the processed serum.

\section{The prophylaxis and treatment of scarlet fever}

Pathological changes in severe scarlet fever, quite apart from tissue invasion and suppuration, have been noted by a long series of authors. Both the earlier literature and extensive autopsy material have recently been reviewed by Brody and Smith (5). The underlying lesion is one of vascular injury with a concurrent perivascular round cell infiltration. These changes were found in from 75 to 95 per cent of the hearts, livers, kidneys, adrenals and spleens and to a variable degree in the other viscera of the fatal cases studied by Brody and Smith. Lesions resembling those described in scarlet fever have been produced experimentally by Hitchcock, Camero and Swift (6) by the intravenous injection of indifferent streptococci into rabbits previously sensitized to streptococci. Whether the characteristic vascular injury in scarlatina is due to circulating streptococcal toxins, as suggested by Brody and Smith, or is allergic as in the case of the experimental lesions of Hitchcock, Camero and Swift, the fact of definite visceral pathological changes in this disease is important and deserves emphasis in view of the current tendency to refer to the mildness of scarlatina and its low mortality.

Convalescent scarlet fever serum as a prophylactic measure in exposed individuals has been reported by Degkwitz (7), Dick and Dick (8), Meader (9), Gordon (10), Hoyne, Levinson and Thalhimer (11) and others. A summary of the results of these authors shows that of nineteen hundred and thirty-three contacts given convalescent scarlet fever serum forty-eight or 2.5 per cent developed the disease. Meader reported that in four hundred and fifty contacts treated with convalescent serum 2.9 per cent developed the disease, whereas in a control group of three hundred and twenty-one contacts not given serum, 12.8 per cent developed scarlet fever.

In spite of the fact that convalescent serum is apparently quantitatively low in antitoxin (12), it has been found in the studies here presented that the majority of cases given the Dick test following the injection of convalescent scarlet fever serum show a quantitative reduction in the Dick reaction if not a complete reversal from positive to negative. In seventeen individuals retested every three to four days for two weeks to a month following the injection of convalescent serum, the average trend showed a change from the positive range to the negative range within the first three days, remaining in the negative range for ten to twelve days and then returned to the positive range. This is graphically demonstrated in Figure 1.2 These findings suggest that a solid protection from an injection of convalescent scarlet fever serum may be expected to last about ten to twelve days, from which time there is a diminishing resistance over two to three weeks.

Included in the present report is a group of forty-seven individuals exposed to scarlet fever

2 The serums used in the cases represented in Figures 1 and 2 were found by Dr. L. J. Wenger to contain less than 10 National Institute of Health units of antitoxin per cc. of serum in comparison with 900 National Institute of Health units of antitoxin per cc. in antiscarlatinal horse serum. 


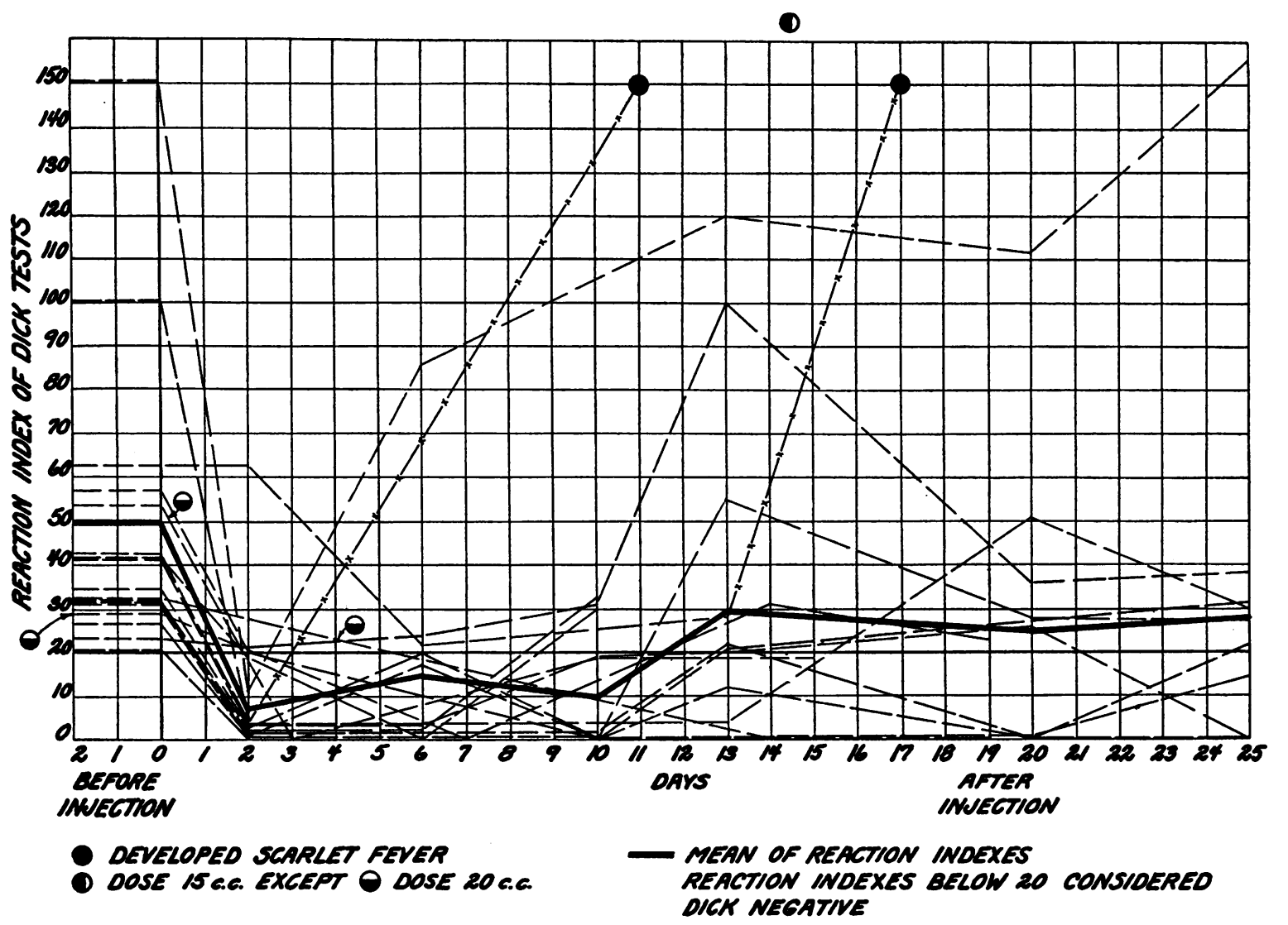

Fig. 1. Effect of Convalescent Scarlet Fever Serum on the Dick Test-17 Cases

The reaction index of the Dick tests is determined by adding the two largest diameters of the Dick reaction which are at right angles to each other and by multiplying this sum of the diameters by the following factors which are measurements of intensity: $\mathrm{F}$ (faint) $=1 ; \mathrm{M}$ (medium) $=1.5 ; \mathrm{B}$ (bright) $=2$; when the medium or bright reactions were also swollen or indurated, an additional 0.5 was added to the intensity factor.

who were given pooled adult serum from Dick negative individuals as a prophylactic measure. Of this group two (Fig. 2) developed very mild scarlet fever. Thirty-three of these individuals were known to be Dick positive and were subjected to a very long and intimate exposure to the disease. As will be seen from Figure 2 such pooled adult serum will likewise produce a quantitative reduction in the Dick test. ${ }^{8}$

It would appear on first examining this chart that the pooled adult serum was more effective in altering the Dick test than the convalescent scarlet fever serum. It is our opinion that this is a false impression, probably due to the fact that

\footnotetext{
8 Presumably the Dick reactions would have been the same immediately preceding the injection of serum as they were when performed 2 days previously.
}

those individuals who were given pooled adult serum had, on the average, Dick tests of less intensity prior to serum injection than did those who were given convalescent serum. It is suggested, however, that, in the absence of convalescent scarlet fever serum, pooled adult serum from individuals with negative Dick tests may be of prophylactic value.

Four hundred and fifty-three individuals, for the most part children, received lyophile convalescent scarlet fever serum following exposure to the disease. One hundred and ninety-three of these cases were known to be Dick positive prior to the serum injection. It is unfortunate that a preliminary Dick test was not carried out in more of the individuals reported. In a disease with such a short incubation period as scarlet fever, parents 


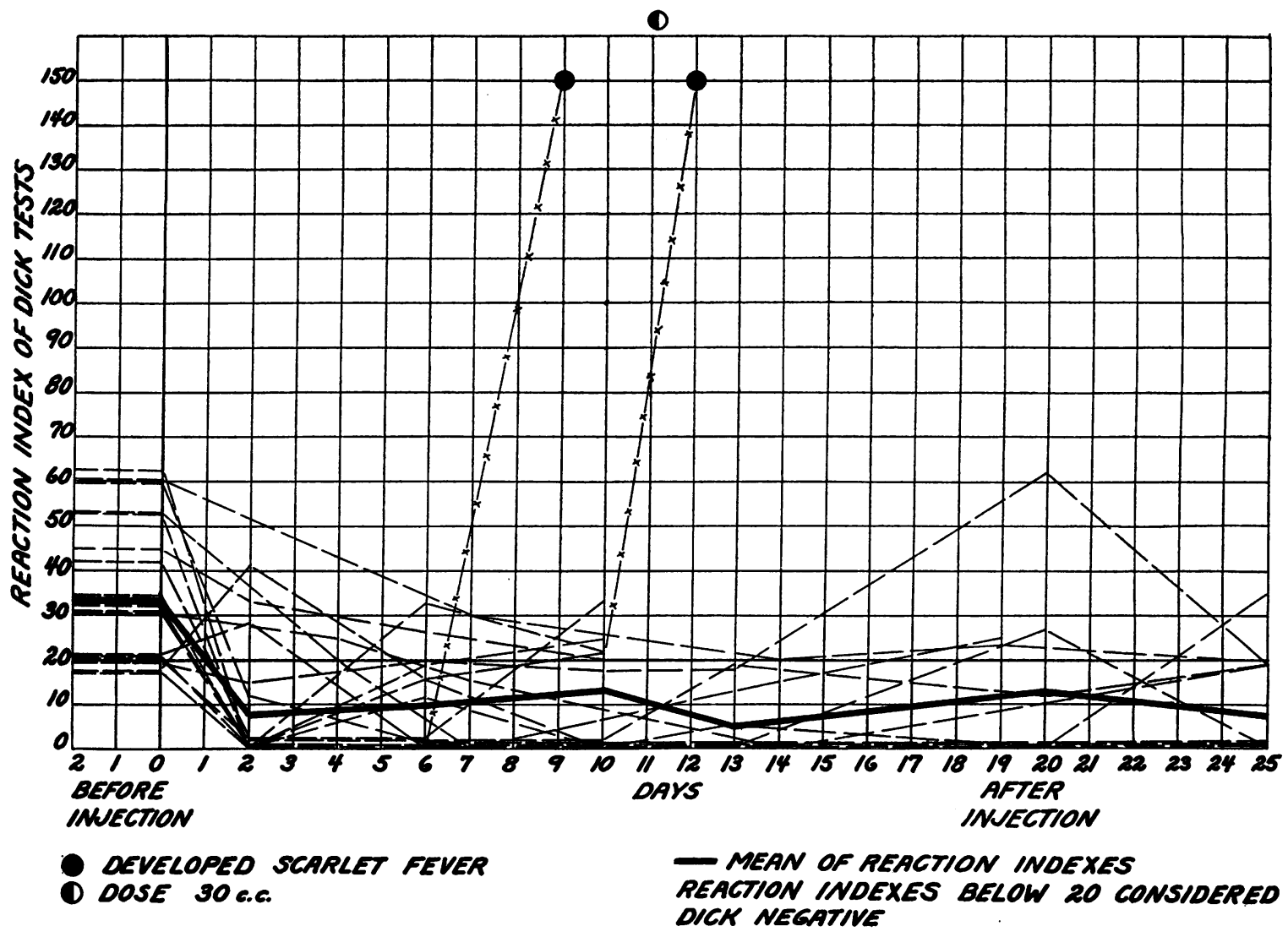

Fig. 2. Effect of Pooled Adult Serum on the Dick Test-17 Cases

and physicians are often unwilling to lose the 24 hours which is necessary for the performance of the test. As will be seen in Table I only eight of the four hundred and fifty-three persons (1.8 per

TABLE I

Prophylaxis against scarlet fever in 500 cases

\begin{tabular}{l|c|c|c|c}
\hline \hline & \multicolumn{2}{|c|}{ Convalescent serum } & \multicolumn{2}{|l}{ Pooled adult serum } \\
\cline { 2 - 5 } & $\begin{array}{c}\text { No } \\
\text { disease }\end{array}$ & $\begin{array}{c}\text { Clinical } \\
\text { cases }\end{array}$ & $\begin{array}{c}\text { No } \\
\text { disease }\end{array}$ & $\begin{array}{c}\text { Clinical } \\
\text { cases }\end{array}$ \\
\hline Home exposure. ........ & $\begin{array}{c}342^{*} \\
103 \|\end{array}$ & $\begin{array}{c}8 \dagger \\
0\end{array}$ & $\begin{array}{c}37 \ddagger \\
8\end{array}$ & $\begin{array}{c}2 \S \\
0\end{array}$ \\
\hline
\end{tabular}

* Dick test known to be positive before injection in 111 cases.

† Dick test known to be positive before injection in 4 cases.

$\ddagger$ Dick test known to be positive before injection in 33 cases.

$\S$ Dick test known to be positive before injection in 2 cases.

\| Dick test known to be positive before injection in 78 cases. cent) injected developed scarlet fever. The data concerning these eight cases follow.

Case 1. C. W., female, age 3 , was given 15 cc. of convalescent scarlet fever serum on December 8, 1934, after an intimate exposure for one day to a brother J. W. who developed clinical scarlet fever on December 7, 1934. J. W. was kept at home, but isolated from the rest of the family. On December 17, 1934, a second brother, P. W., developed what may have been a subclinical case of scarlet fever which may have reexposed C. W. On December 26, 1934, nineteen days following her initial exposure, C. W. developed typical mild scarlet fever. Her temperature never rose above $101^{\circ} \mathrm{F}$.

Case 2. R. D., male, age 15 (Fig. 1), was given 15 cc. of convalescent scarlet fever serum on February 15, 1936. This boy was a student in a boarding school of one hundred and sixty-seven individuals, where there had been fourteen cases of scarlet fever in the preceding five weeks. One hundred and thirty-one of the one hundred and sixty-seven members of the school family had throat cultures positive for the hemolytic streptococcus on February 13, 1936, and exposure in this case was probably intimate and prolonged. Ten days following the injection of the convalescent serum, R. D. developed a 
marked rash, typical of scarlet fever, which lasted for one day. His temperature remained below $100^{\circ} \mathrm{F}$. at all times, and he made a rapid and uneventful recovery.

Case 3. B. O'B., female, age 30 (Fig. 1), was given 15 cc. of convalescent scarlet fever serum on February 15,1936 . This individual was a secretary in the same school mentioned in Case 2, and exposure was likewise presumed to be long and intimate. On February 26, 1936, eleven days following the injection of the serum, she developed a mild case of scarlet fever with a moderate rash, a very sore throat, and a temperature of $101^{\circ} \mathrm{F}$. She was given $30 \mathrm{cc}$. of convalescent scarlet fever serum, and her temperature reached normal in about 36 hours from the time the serum was given.

Case 4. H. T., female, age 8 , was given $15 \mathrm{cc}$. of convalescent scarlet fever serum on February 10, 1936. She was intimately exposed to a sister who developed scarlet fever on February 9, 1936, and remained in the same house with her sister during the latter's illness. On February 23, 1936, fourteen days after onset of her sister's illness, and thirteen days after the injection of the serum, $H$. T. developed a very mild case of scarlet fever. She was given $30 \mathrm{cc}$. of convalescent serum at that time, and her temperature was normal by the next day.

Case 5. D. T., female, age 10, was a sister of Case 4 and was exposed under similar circumstances. She was given 15 cc. of convalescent scarlet fever serum on February 10,1936, and developed a barely distinguishable case of scarlet fever on February 30, 1936, twenty-one days after her initial exposure and twenty days after the injection of the serum. The course of her disease was afebrile throughout.

Case 6. M. B., female, age 2, was given $5 \mathrm{cc}$. of convalescent scarlet fever serum, considered an inadequate dose, on February 24, 1936. She was intimately exposed for three days to a sister who developed scarlet fever on February 22, 1936. The sister was isolated from the other children on the third day of her clinical disease, but remained in the same house. M. B. developed typical moderately severe scarlet fever with a temperature at the onset of $103^{\circ} \mathrm{F}$., on March 12, 1936, nineteen days after her initial exposure and seventeen days after the injection of the serum. Her temperature dropped to normal within twenty-four hours following the injection of 30 cc. of convalescent scarlet fever serum.

Cases 7 and 8. M. B. and J .B., brothers, age 9 and 10 , were first exposed to a brother who developed scarlet fever on October 17th, 1936. They were isolated from this brother, but remained in the same house. On October 19th, they were given lyophile serum, M. B. receiving a mixture consisting of $10 \mathrm{cc}$. of convalescent scarlet fever serum and $10 \mathrm{cc}$. of pooled adult serum, and J. B. receiving $20 \mathrm{cc}$. of convalescent scarlet fever serum. M. B. developed mild scarlet fever on October 22d, and J. B. developed a mild case of the disease on October 24th, five and seven days respectively following their initial exposure, and three and five days after the injection of the serum. Both cases were complicated by cervical adenitis.
It is of interest that all eight of the cases just described remained either in the same house or in the same boarding school with scarlet fever cases from the time of their initial exposure until they developed the disease. Six of the eight cases developed scarlet fever between the tenth and twentieth day following the injection of convalescent serum. In view of these findings and in view of the fact that quantitative reversal of the Dick test following the injection of convalescent serum remains for only ten or twelve days, it would appear wise wherever such intimate contact occurs to administer serum every ten days until the causative organisms have disappeared from the throat of the patient with scarlet fever.

Convalescent serum for the treatment of toxic cases of scarlet fever has been employed by a number of investigators beginning with Weisbecker (13), in 1897. Gordon, Bernbaum and Sheffield (14), in 1928, stated that serum from convalescents had been established as a valuable therapeutic measure. They concluded that convalescent serum and antitoxic horse serums are equally effective in reducing fever, duration of skin lesions, complications, and fatality rate. Convalescent serum has the added advantage in that it does not produce the serum sickness which follows in about 33 per cent of the cases treated with horse serum.

Hoyne, Levinson and Thalhimer (11) have recently reported their results with the use of convalescent scarlet fever serum in the treatment of nine hundred and forty-seven patients. They divided their cases into hospital and home groups; in the hospital group good results were recorded in 75 per cent of the cases, fair results in 11 per cent, and questionable or no results in 14 per cent. In the home group good results were recorded in 81 per cent, fair results in 8 per cent, and questionable or no benefit in 11 per cent. Also they reported that septic complications were fewer in treated cases than in a comparable group of untreated cases.

In the present study, seventy-eight cases of scarlet fever have been treated with convalescent scarlet fever serum. Twelve of these individuals had very mild cases of the disease prior to treatment, and probably would not have been treated had not the attending physicians in question been particularly anxious to prevent the occurrence of 
any complications. The remaining sixty-six cases could be classified previous to treatment as moderate or severe. The majority of these cases were given a single injection of convalescent serum, the dose varying from 30 to $60 \mathrm{cc}$. In several instances, the initial dose was repeated once, and in one case twice, the largest amount of serum received by any individual case being $120 \mathrm{cc}$.

It is difficult to determine the value of the serum in the twelve very mild cases except to say that they developed no complications. Of the fifty-six moderately severe and severe cases of scarlet fever studied, forty-eight responded favorably to the convalescent serum. In the majority of these cases the temperature reached normal within about thirty-six hours of the time the serum was given; and within the same time the rash had begun to fade, the toxic manifestations had disappeared, and the patients appeared to be convalescent. Eight cases failed to show any remarkable response to serum therapy.

Complications developing among the sixty-eight treated cases of scarlet fever were few in number and may be listed as follows:

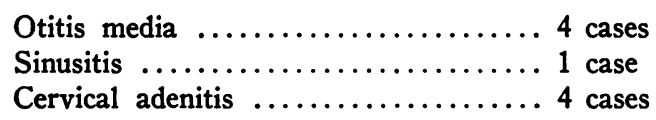

\section{Prophylaxis against measles}

The value of convalescent and immune adult serums in prophylaxis against measles is well recognized.

There is no general agreement concerning the optimum time for drawing serum from persons recently convalescent from measles. Apparently this serum is potent from the time defervescence occurs up to at least a year following the disease. In these studies, blood for convalescent serum was taken only from persons who had had measles within the preceding year, and it appeared preferable to bleed them in the first three or four months following their illness.

In the analysis of the present results the cases are tabulated as completely protected, attenuated, or receiving no apparent protection. The disease was considered attenuated if the temperature did not rise above $101^{\circ} \mathrm{F}$. at any time, and did not last for more than two days as a maximum. Any case of greater severity was listed as receiving no protection.
When the difference in dosage is omitted from consideration very similar results were obtained with convalescent measles and pooled normal adult serums.

As observed by other workers, attenuation of the disease is preferable to complete protection except for very delicate children, infants, and certain hospitalized children.

The results recorded agree in general with those of other workers, i.e., pooled adult serum is quite as effective as convalescent serum. However, the concentration possible with lyophile serum makes the size of the dose comparatively unimportant; for this reason in the present studies less of the more costly and scarce convalescent serum has been used and more of the pooled adult serum which can be had in any quantity desired at a relatively low cost.

The majority of workers feel that little effect is to be obtained when serum is injected later than the seventh day following the initial exposure. Four of the seven cases in the series who developed typical unmodified measles received their serum on the seventh day following their first exposure. In contradistinction to this, several cases receiving injections later than the seventh day appeared to be protected. Final conclusions may not be drawn, but on the whole, our results, together with those of other investigators, show that late injections provide less protection. Some workers, including Debré and Ravina (15), employ a standard dosage, giving the injection early in the incubation stage if they desire complete protection, and later if modification only is desired. This method appears to be a better means of regulating the severity of the attack than does the modification of the dosage. However, it is impossible in many instances to select the proper date for injection.

It is generally conceded in measles also that pooled serum is better without particular regard to the time that the donor may have had measles. In three children, not included in the cases tabulated in Table II, typical measles developed following the injection of $2.4 \mathrm{cc}$. per year of age of serum drawn from a single adult donor.

The results with the use of convalescent and pooled adult serum in prophylaxis against measles can be seen from Table II. None of the cases re- 
TABLE II

Prophylaxis against measles in 410 cases

\begin{tabular}{l|c|c|c|c|c|c}
\hline \hline & \multicolumn{3}{|c|}{ Convalescent serum } & \multicolumn{2}{|c}{ Pooled adult serum } \\
\cline { 2 - 7 } & $\begin{array}{c}\text { No } \\
\text { dis- } \\
\text { ease }\end{array}$ & $\begin{array}{c}\text { Atten- } \\
\text { uated }\end{array}$ & $\begin{array}{c}\text { Clin- } \\
\text { ical } \\
\text { cases }\end{array}$ & $\begin{array}{c}\text { No } \\
\text { dis- } \\
\text { ease }\end{array}$ & $\begin{array}{c}\text { Atten- } \\
\text { uated }\end{array}$ & $\begin{array}{c}\text { Clin- } \\
\text { ical } \\
\text { cases }\end{array}$ \\
\hline Home exposure.... & 40 & 30 & 5 & 94 & 63 & 2 \\
Hospital exposure. . & 37 & 6 & 3 & 116 & 10 & $4^{*}$ \\
\hline
\end{tabular}

* Dose-2.5 cc. per year of age injected on 7th day of continuous intimate exposure.

ceiving either type of serum suffered any sequellae. The results compare favorably with those reported by other workers concerning the use of fresh serum or placental extract (16).

Although several workers have published reports on the treatment of measles with convalescent serum, the use of the lyophile convalescent serum therapeutically has only been attempted in a few cases and no conclusions may be drawn. Reports concerning the use of convalescent serum for treatment have not been encouraging.

\section{Prophylaxis and treatment of mumps}

Alfred Hess (17) in 1915 first reported the use of convalescent serum for prophylaxis in mumps. Skrotskiy (18) reported the intramuscular injection of from 5 to $15 \mathrm{cc}$. of convalescent serum in one hundred and seventy-nine children exposed to mumps. In this group two mild cases of mumps developed, and the remainder appeared to be completely protected. Cambessédès (19) in 1933 reported the successful use of convalescent serum in prophylaxis and also considered that he used this serum to good advantage in the treatment of the disease, reducing by this means the incidence of orchitis. Barenberg and Ostroff (20) reported the use of adult whole blood as well as convalescent whole blood in prophylaxis against mumps, and found that 15 per cent of those injected developed the disease compared with 39 per cent in a control group. Kereszturi, Hauptman and Park (21) were unable to draw any conclusions from their study.

Convalescent and pooled normal adult serum have been used in the present studies (Table III). Nine cases developed among one hundred and forty exposed individuals, six in the group receiving convalescent serum, and three in the
TABLE III

Prophylaxis against mumps in 140 cases

\begin{tabular}{l|c|c|c|c}
\hline \hline & \multicolumn{2}{|c|}{ Convalescent serum } & \multicolumn{2}{|c}{ Pooled adult serum } \\
\cline { 2 - 5 } & $\begin{array}{c}\text { No } \\
\text { disease }\end{array}$ & $\begin{array}{c}\text { Clinical } \\
\text { cases }\end{array}$ & $\begin{array}{c}\text { No } \\
\text { disease }\end{array}$ & $\begin{array}{c}\text { Clinical } \\
\text { cases }\end{array}$ \\
\hline Home exposure......... & 63 & 5 & 8 & 1 \\
Hospital exposure..... & 15 & 1 & 45 & 2 \\
\hline
\end{tabular}

smaller group receiving pooled adult serum. Two of these children developed mumps without any attenuation, twenty-five and thirty-five days respectively, following the administration of presumably adequate doses of convalescent serum. In another child mumps developed twenty-four days following the administration of $20 \mathrm{cc}$. of pooled adult serum. In these cases, the possibility of re-exposure was excluded. The virus of mumps may have remained quiescent in the presence of protective antibodies, only to become active again when these antibodies became exhausted. Three cases developed mumps on the fifth, seventh and eighth day, respectively, following the administration of serum, and in these cases it is felt that serum was given too late in the course of the incubation period to have been of value. One case, 27 years of age, developed typical mumps seventeen days following a prophylactic injection of only $10 \mathrm{cc}$. of pooled adult serum. There is no satisfactory explanation for the development of the disease in the other two non-protected individuals.

The majority of cases treated at home were thoroughly exposed to proven cases of mumps. Thirty-two cases reported in the hospital group were exposed to a resident physician who, after contracting the disease, with visible parotid swelling, examined every nose and throat on his ward. None of these thirty-two individuals developed mumps.

No data were available concerning the optimum time to draw serum from persons convalescent from mumps. For this reason six months was arbitrarily taken as the maximum time that should have elapsed from the onset of the disease to the withdrawal of blood. Further data will be necessary before definite conclusions can be drawn as to the optimum time.

Like chickenpox, mumps in children is consid- 
ered to be a rather innocuous disease and one which is best contracted before puberty ushers in the hazard of a complicating orchitis or oophoritis. It is the fear of these complications which caused many adults to request an injection of serum for themselves following exposure to mumps in their children. These results suggest that convalescent and pooled adult serums may be effective in the prevention of mumps in exposed individuals.

A single case ${ }^{4}$ of severe orchitis in mumps was treated with $50 \mathrm{cc}$. of convalescent mumps serum on three successive days, beginning with the fifth day of the orchitis. On the third day of treatment the temperature dropped to normal by crisis, and the boy made an uneventful recovery. It cannot be determined whether or not the serum was the deciding factor in this case. From reports in the literature convalescent mumps serum would appear to be a valuable therapeutic measure in this type of orchitis.

\section{Prophylaxis against chickenpox}

The successful use of convalescent chickenpox serum for prophylaxis has been reported by Blackfan, Peterson, and Conroy (22), Mitchell and Ravenel (23), Gordon and Meader (24), and Lewis and Barenberg (25) and by several others. Chickenpox in children is considered a fairly innocuous disease, but is a scourge once it has established itself in a pediatric ward, and for this reason it is in the hospital that prophylaxis is most often sought. The majority of cases reported here are taken from hospital practice where the expected case rate of chickenpox is much lower than that generally found in private practice, although higher than that of mumps and scarlet fever. In the experience of Gordon and Meader (24), 68 per cent of susceptible children exposed to chickenpox in a hospital and not treated contracted the disease.

Gordon and Meader have pointed out that the protective properties of convalescent varicella serum are markedly diminished after three months following defervescence. For this reason the attempt was made to collect the serum within this period. Pooled adult serum was employed in a number of cases and while complete protection

4 We are indebted to Dr. John A. Young of Newport, R. I., for the data on this case. was secured in a moderate percentage of those treated, pooled adult serum did not appear to be as effective in the prophylaxis of chickenpox as in that of measles. Lewis and Barenberg (25) employed a dosage of $30 \mathrm{cc}$. of adult whole blood in an attempt to protect five individuals from chickenpox, but all five contracted the disease in mild form. With adult serum, however, they apparently protected eight cases with a dose of 40 cc. Most of the published reports deal with the use of convalescent serum.

TABLE IV

Prophylaxis against chickenpox in 157 cases

\begin{tabular}{l|c|c|c|c}
\hline \hline & \multicolumn{2}{|c|}{ Convalescent serum } & \multicolumn{2}{|c}{ Pooled adult serum } \\
\cline { 2 - 6 } & $\begin{array}{c}\text { No } \\
\text { disease }\end{array}$ & $\begin{array}{c}\text { Clinical } \\
\text { cases }\end{array}$ & $\begin{array}{c}\text { No } \\
\text { disease }\end{array}$ & $\begin{array}{c}\text { Clinical } \\
\text { cases }\end{array}$ \\
\hline Home exposure ........ & 4 & 7 & 15 & 3 \\
Hospital exposure..... & 42 & 1 & 71 & $14^{*}$ \\
\hline
\end{tabular}

* 6 of these cases given an inadequate dose of $7.5 \mathrm{cc}$.

The results in one hundred and fifty-seven cases may be seen in Table IV. It may be noted that a number of failures occurred with relatively small doses of pooled adult serum. Several children receiving what were considered adequate doses of convalescent serum developed the disease without any evidence of attenuation. Three infants in private practice given $10 \mathrm{cc}$. of convalescent serum within the first three or four days following a heavy exposure to members of their own families, developed a very mild form of chickenpox consisting of 4 to 10 typical lesions but without any elevation in temperature. These results, although in general satisfactory, are not as conclusive as those recorded above in scarlet fever and measles.

\section{The treatment of erysipelas}

The use of convalescent erysipelas serum for the treatment of this disease was first described by Fornaca (26) in 1905; Jordan and Dustin (27), and several others have more recently described the use of this serum with favorable results.

Three severe cases of erysipelas, two facial and one of the leg, have been treated with lyophile convalescent erysipelas serum. These cases made 
good recoveries, and injection of the serum was followed by a fall in temperature, reduction in toxemia, and fading of the rash. These patients received from two to four injections of serum, each amount injected varying from 30 to $60 \mathrm{cc}$. No other special therapy such as $\mathrm{x}$-ray, ultraviolet light, or horse serum, was employed in the treatment of these cases.

In view of the fact that immunity to the hemolytic streptococcus of erysipelas is believed to disappear rapidly in certain cases following recovery from the disease (Birkhaug (28)), it is suggested that blood for convalescent serum be drawn when feasible within six weeks after defervescence.

\section{Prophylaxis and treatment of whooping cough}

Bradford (29) has recently reviewed the literature concerning the use of convalescent and immune adult whole blood and serum in the prevention and treatment of whooping cough. The general opinion seems to be that these serums may be effective in the prevention of the disease, although the reports concerning the results in treatment are not conclusive.

Pooled adult serum has been used in these studies in prophylaxis against whooping cough in one small group of twelve infants between the ages of one and seven months. These children were exposed in a ward to a frank case of pertussis who was kept on the ward for two weeks following the onset of the disease, and subsequently died of pertussis bronchopneumonia. Serum was injected on the twelfth day following the initial exposure, eight of the infants receiving $10 \mathrm{cc}$. of serum and the remaining four $20 \mathrm{cc}$. None of these infants developed whooping cough. One child of 10 years was given $20 \mathrm{cc}$. of pooled adult serum following a two day exposure to a sister with the disease. This child also did not develop whooping cough.

Jundell (30) in 1933 reported the use of blood from individuals who had recently had an injection of fresh whooping cough vaccine in the treatment of five cases of whooping cough. It was his feeling that these cases responded well to the blood. For the past ten months we have been injecting several healthy adults with the routine course of Sauer's whooping cough vaccine, giving one full course of vaccine every four months. At the end of the first four months these donors have been bled, and the bleedings have been repeated at varying intervals thereafter. All of the donors give a history of having had whooping cough in childhood. A good opportunity for testing the serum from the donors has not as yet arisen. It has been given to twelve children intimately and continuously exposed to siblings with whooping cough. Previous attacks of whooping cough could be definitely excluded in these cases. Six of these children never developed the disease. Three developed a cough which lasted for from ten days to two weeks, but which was not associated with a characteristic whoop. The remaining three children developed typical but mild whooping cough. Fifteen cases of whooping cough have been treated with this type of serum after the onset of the disease. Five appeared to be much improved after the injections, but the value of the serum in the remaining ten cases was questionable.

No conclusions may be drawn at present concerning the use of " hyperimmune" human serum in whooping cough. Results so far indicate that it may be of value for passive protection against the disease. The benefit to be derived from the serum once the disease has become active is uncertain.

\section{Prophylaxis against German measles}

German measles is such an innocuous disease that it might almost seem unwise to make any attempt to prevent its occurrence. In spite of this fact, there are times when it is desirable to prevent its spread in a hospital ward. Also there are occasions when for various reasons it would be inconvenient and sometimes even serious for a child in a private home to develop the disease. Pooled adult lyophile serum has been used in one outbreak of German measles in the ward on which occasion ten infants between the age of 6 and 10 months and one infant of 4 months were each injected with $10 \mathrm{cc}$. of this serum on the day that a typical case of German measles developed in the ward. Two additional cases developed the following two days, and all three cases remained on the ward throughout their disease. Of the eleven children receiving serum, one de- 
veloped the disease twelve days after the initial exposure. The rest remained well.

Two infants of 18 months were each given 10 cc. of pooled adult serum three and five days respectively following an intimate exposure at home. Neither of these infants developed German measles.

\section{The treatment of acute hemolytic streptococcal infections}

Thalhimer and Levinson (31) have recently reported on the use of pooled convalescent scarlet fever serum in the treatment of " diverse streptococcic infections" such as cervical adenitis following a streptococcic sore throat, "sepsis" and septic complications, acute streptococcal pharyngitis, purulent otitis media, streptococcic pneumonia, etc. Their results appeared to be excellent in 11 per cent of the cases studied, good in 44 per cent, doubtful in 17 per cent and without benefit in 28 per cent.

A relatively small series of cases of hemolytic streptococcal infections has been treated with pooled lyophile convalescent scarlet fever serum, and while no final conclusions may be drawn from these studies, the results obtained in a number of instances have suggested considerable benefit from this therapy.

Six cases of acute hemolytic streptococcal laryngitis have been treated with from 40 to $120 \mathrm{cc}$. of lyophile convalescent scarlet fever serum. Three of these cases appeared to respond rather dramatically with a rapid fall in temperature, reduction in toxemia, and diminution in the throat symptoms. The other three cases recovered, but the reduction in fever and toxemia following the injection of serum was not striking.

Three cases of hemolytic streptococcal meningitis have been treated by intraspinal injections of convalescent scarlet fever lyophile serum. Two cases appeared to be benefited for a short time as indicated by a temporary but marked reduction in the number of cells in the spinal fluid, and by a temporary disappearance of the organisms following the injections. These two cases finally died. The third case ${ }^{5}$ made a complete recovery. In this case diagnosis was made and a

5 We are indebted to Dr. John P. Scott and Dr. Samuel $\mathrm{X}$. Radbill for the data on this case. bilateral mastoidectomy performed on what was presumably the fifth day of the disease. The day following the operation a blood transfusion was given and on the next three successive days $30 \mathrm{cc}$. of convalescent scarlet fever serum was given intraspinally as well as $30 \mathrm{cc}$. of serum intramuscularly. Spinal fluid culture was positive on the fourth day following operation but the plates only showed 2 to 3 colonies, whereas the spinal fluid immediately preceding and after operation showed many organisms on direct smear as well as on culture. By the fifth day after operation and the third day after the initiation of serum therapy the temperature was normal, and remained normal thereafter. Thirteen days after operation, and eleven days after the first dose of serum the child was convalescent, and the spinal fluid was clear, negative to culture, and contained only 42 cells per cubic millimeter.

Seven cases of severe hemolytic streptococcal sore throat have been treated with convalescent lyophile scarlet fever serum, and all of these cases appeared to be benefited. Two cases of acute mastoiditis with suppurative otitis, of hemolytic streptococcal origin, were treated with the same type of serum and recovered, but the value of the serum in these cases was masked by the repeated blood transfusions which were given in addition to the serum.

One case of puerperal sepsis with an associated hemolytic streptococcal septicemia was treated with one $300 \mathrm{cc}$. blood transfusion and three injections of $40 \mathrm{cc}$. of convalescent scarlet fever serum given at twelve hour intervals. This individual made a rapid and uneventful recovery.

One case of hemolytic streptococcal septicemia of obscure origin died following treatment with convalescent scarlet fever serum, repeated blood transfusions, and antistreptococcal horse serum.

\section{Reactions}

Moderately severe reactions have occurred in only five instances in over fifteen hundred injections of lyophile serum. These children all developed a temperature of about $104^{\circ} \mathrm{F}$., local tenderness and swelling, and marked malaise, all symptoms starting within the first four to six hours following the injections and lasting 36 to 48 hours. One of these children developed a pur- 
puric rash which disappeared within 12 hours. These five reactions followed the administration of serum which had been prepared during the early part of the work, and which was markedly hemolyzed. Whether or not hemolysis had anything to do with these reactions we cannot be sure. It seems significant, however, that from the time the serum was produced with very few hemolyzed cells this severe type of reaction was no longer noted.

Twelve children developed local pain and tenderness with an elevation in temperature of from one to three degrees with slight general malaise such as follows typhoid vaccination. Seven of these children received serum from two small lots prepared early in the studies. This type of reaction usually disappeared overnight.

Lyophile serum when injected intramuscularly causes no greater soreness than the same amount of fresh human serum which has not been processed. This soreness rarely lasts for more than a day, and in the majority of instances there have been no complaints at all.

The amount of serum and the concentration of the serum seemed to bear little relation to the severity of the reactions. The most severe reactions followed doses of about $10 \mathrm{cc}$. or less of serum. As much as $80 \mathrm{cc}$. of serum (doubly concentrated) has been given at one injection without any reaction whatever other than muscle tenderness lasting overnight. Abscess formation or tissue necrosis has never followed the injection of lyophile serum.

Serum sickness, such as frequently follows the injection of horse serum, has never been noted in any of these cases. Such reactions have been reported in a few cases following the injection of liquid human serum (32).

It is well known that an allergic reaction may occur following the injection of serum from a donor who has recently eaten food to which the recipient is markedly sensitive. For this reason the donors are bled, whenever possible, in the morning when they have had no heavy meal for some hours.

\section{SUMMARY}

The use of human serums preserved by the lyophile process in the prophylaxis of scarlet fever, measles, mumps, chickenpox, whooping cough, and German measles, and in the treatment of scarlet fever, mumps, erysipelas, whooping cough, and acute hemolytic streptococcic infections is described. Particular emphasis has been laid on the use of serum from large pools of normal healthy adult blood in the prophylaxis of the more common contagious diseases.

The results obtained compare favorably with those reported by other investigators who have employed fresh serums or serums preserved in the liquid state. Certain distinctive advantages of lyophile serums (2) are indicated and illustrated with case material.

We are indebted to Miss Janet Armstrong for assistance in the collection of blood, to Dr. Arthur D. Waltz and Miss Belita de Ayala of the Children's Hospital Laboratory for the Kahn reactions, and to Dr. L. J. Wenger for assistance in the performance and reading of the Dick tests involved in the preparation of Figures 1 and 2. The lyophile serum for the past two years has been processed at the Mulford Laboratories of Sharp and Dohme. This work has been aided by a generous grant from the Board of Managers of the Abington Memorial Hospital, and by the interest and foresight of its Medical Director, Dr. Harry B. Wilmer.

\section{BIBLIOGRAPHY}

1. Flosdorf, E. W., and Mudd, S., Procedure and apparatus for preservation in "Lyophile" form of serum and other biological substances. J. Immunol., 1935, 29, 389.

2. Mudd, S., Flosdorf, E. W., Eagle, H., Stokes, J., Jr., and McGuinness, A. C., The preservation and concentration of human serums for clinical use. J. A. M. A., 1936, 107, 956.

3. Stokes, J., Jr., McGuinness, A. C., and Mudd, S., Clinical applications of the lyophile process. Am. J. Dis. Child. (Proc.), 1935, 50, 535.

4. Stokes, J., Jr., Mudd, S., Roddy, R. L., Eagle, H., Flosdorf, E. W., and Lucchesi, P., The use of lyophile human serums for prevention and treatment in infectious diseases. Am. J. Dis. Child. (Proc.), 1934, 48, 1428.

5. Brody, H., and Smith, L. W., The visceral pathology in scarlet fever and related streptococcus infections. Am. J. Path., 1936, 12, 373.

6. Hitchcock, C. H., Camero, A. R., and Swift, H. F., Perivascular reactions in lung and liver following intravenous injection of streptococci into previously sensitized animals. J. Exper. Med., 1934, 59, 283.

7. Degkwitz, R., Zum Scharlachproblem. München. med. Wchnschr., 1922, 69, 955.

8. Dick, G. F., and Dick, Gladys, H., The prevention of scarlet fever. J. A. M. A., 1924, 83, 84. 
9. Meader, F. M., Scarlet fever prophylaxis, use of blood serum from persons who have recovered from scarlet fever. J. A. M. A., 1930, 94, 622.

10. Gordon, J. E., Quoted by Hoyne, Levinson and Thalhimer (11).

11. Hoyne, A. L., Levinson, S. O., and Thalhimer, W., Convalescent scarlet fever serum. Its prophylactic and therapeutic value. A review of 2,875 cases. J. A. M. A., 1935, 105, 783.

12. Rhoads, P. S., and Gasul, B. M., Convalescent scarlet fever serum and commercial antitoxin. A comparison of their protective values. J. A. M. A., 1934, 102, 2005.

13. Weisbecker, Heilserum gegen Typhus, Scharlach, Pneumonie. Ztschr. f. klin. Med., 1897, 32, 188.

14. Gordon, J. E., Bernbaum, B. B., and Sheffield, L. C., Convalescent and antitoxic serums in scarlet fever. A comparison of results in 1,508 cases. J. A. M. A., 1928, 90, 1604.

15. Debré, R., and Ravina, J., La Rougeole Modifiée par L'Injection Préventive de Sérum de Convalescent. Bull. et mém. Soc. méd. d. Hôp. de Paris, 1923, 47, 226.

16. Robinson, E. S., and McKhann, C. F., Immunological application of placental extracts. Am. J. Pub. Health, 1935, 25, 1353.

17. Hess, A. F., A protective therapy for mumps. Am. J. Dis. Child., 1915, 10, 99.

18. Skrotskiy, A. I., Seroprophylaxis of epidemic parotitis. Odessky M. J., 1929, 4, 8.

19. Cambessédès, H., L'emploi du Sérum de Convalescents dans les Oreillons. Ann. d'hyg., 1933, 11, 83.

20. Barenberg, L. H., and Ostroff, J., Use of human blood in protection against mumps. Am. J. Dis. Child., 1931, 42, 1109.

21. Kereszturi, C., Hauptman, D., and Park, W. H., Value of convalescent serum for the prevention of the common contagious diseases of children. Am. J. Dis. Child., 1935, 50, 309.
22. Blackfan, K. D., Peterson, M. F., and Conroy, F. C., Use of convalescent serum as a prophylaxis in measles and chickenpox. Ohio State M. J., 1923, 19, 97.

23. Mitchell, A. G., and Ravenel, S. F., The value of convalescents' serum in protection against varicella. Arch. Pediat., 1925, 42, 709.

24. Gordon, J. E., and Meader, F. M., The period of infectivity and serum prevention of chickenpox. J. A. M. A., 1929, 93, 2013.

25. Lewis, J. M., and Barenberg, L. H., The use of convalescent serum in the treatment of measles, chickenpox, mumps, and whooping cough, including the prophylactic value of parental blood. New York State J. Med., 1933, 33, 97.

26. Fornaca, L., Osservazioni sulla erisipela; tentativi di sieroterapia col siero di convalescente; note batteriologische. Policlinico (sez. med.), 1905, 12, 307.

27. Jordan, H. P. B., and Dustin, C. C., Convalescent serum in the treatment of erysipelas. A report of its use at the Providence City Hospital. J. A. M. A., 1924, 82, 874.

28. Birkhaug, K. E., Erysipelas. VI. Immunization with soluble toxin from streptococcus erysipelatis against recurrent attacks of erysipelas. J. A. M. A., 1927, 88, 885.

29. Bradford, W. L., Use of convalescent blood in whooping cough, with a review of the literature. Am. J. Dis. Child., 1935, 50, 918.

30. Jundell, I., Has specific serum of adults any value as a remedy against whooping cough? Acta paediat., 1933, 15, 1.

31. Thalhimer, W., and Levinson, S. O., Pooled convalescent scarlet fever serum treatment of diverse streptococcic infections. J. A. M. A., 1935, 105, 864.

32. Current Comment. Sudden death after injection of human serum. J. A. M. A., 1934, 103, 192. 